\title{
The Role of Financial Intermediaries in the Internationalization of Capital Markets in Kenya: A Study of stock brokers in Kenya
}

\author{
${ }^{1}$ Robert Arasa, ${ }^{2}$ Monicah Mwaniki, ${ }^{1}$ Prudensia Kaihula, \\ ${ }^{1}$ Catholic University of Eastern Africa \\ ${ }^{2}$ Strathmore University, Kenya \\ rarasa4@gmail.com
}

\begin{abstract}
Financial intermediaries continue to play a big role in the internationalization of capital markets. In Kenya all transactions in the Nairobi Securities Exchange must be carried out by an authorized stock broker. This study covered the stockbrokers and their role in the internationalization of capital markets within Kenya. The study adopted a descriptive survey. Population of interest comprised of 19 stockbrokerage firms licensed to operate at the Nairobi Securities Exchange (NSE). The study findings indicate that stock brokers contribute to the internationalization of capital markets through their roles in facilitating cross-listing, offshoring and foreign investor by aiding in sourcing for investment opportunities, provision of relevant information and transaction facilitation. Study findings further reveals that the government issues, lack of awareness and knowledge on innovative strategies, adequate financial resources, availability of adequate infrastructure and trading costs affects stock brokers role in the internationalization of capital markets. The study recommends that the government and policy makers should direct efforts towards addressing the various bottlenecks that hinder the effectiveness of the stock brokers in the internationalization of capital markets in Kenya. Further, towards realizing efficiency and effectiveness these firms need to embrace technology and innovation.
\end{abstract}

Keywords: Stock brokers, capital markets, internationalization, cross-listing, foreign investment, off-shoring

\section{Introduction}

From the late 1990's, there has been unprecedented deregulation of financial market processes as well as globalization of financial markets. Developed and developing countries have therefore unwrapped their financial systems, permitting foreign competition and the free transition of capital across borders. Europe has particularly witnessed great strides towards financial liberalization that has seen the abolishing of capital controls and the adoption of Single Market programs (Sparrow, Farndale \& Scullion, 2013). They say this had the aim of levelling the platform against which financial institutions and brokers could engage in. Ultimately, such developments have fostered markets integration towards the internationalization of Capital Markets. Capital markets promote economic efficiency by channelling money from those who do not have an immediate productive use for it to those who do at a gain (Bluhm, Harman, Lee \& Mitchell, 2011). Stocks and bonds markets are the two major commodities in the Kenyan capital market. Although by regional standards, Kenya's financial system is relatively well developed and diversified, major structural impediments prevent it from exploiting its full potential especially in the internationalization of its capital markets and as facilitated by stockbrokerage firms (Benito, Petersen \& Welch, 2009). Cross-country comparisons, however, show the importance of a well-developed financial sector for long-term economic growth through the internationalization of Kenya's capital market. Analyzing and decomposing the high interest rate spreads and margins in Kenya helps identify structural impediments that drive the high cost and low access of financial services such as the capital markets (Fonfara, 2011).

Kenya makes a vital case study for evaluating the success of financial sector reforms in a developing country. In this respect, it is listed among one of few studies, which conduct an analysis on the effect of reforms on the level of competition within the financial context in Africa. However, there are concerns that the recent reforms, especially the consolidation within the banking context, may have provided a result of a sound, yet still uncompetitive system that could fail in delivery on a greater access and financial strengthening, despite the fact that profits could go up. If the Kenyan Capital Market is anything to go by in terms of its 
internationalization, the fact that foreign investors have been the major force of share price increase in the recent past is an indicator that financial brokers are evidently doing something due to the fact that these activities occur through them (Mugwe, 2012).

Stockbrokers continue to play a big role in the internationalization of capital markets, particularly in Kenya since all transactions in the Nairobi Securities Exchange must be carried out by an authorised stockbroker. The level of internationalization in the Kenyan capital market is a problem that has affected adversely the levels of revenues earned within the international market. Various studies have been carried out on capital markets as well as internationalization in general with a focus on various angles. Trąpczyński \& Wrona (2013) focused on internationalization as a major dimension of the ongoing strategy process of most business firms. Trąpczyński, and Wrona looked at how internationalization determines the ongoing development and change in the international firm in terms of scope, business idea, action orientation, organizing principles, nature of managerial work, dominating values and converging norms. This study set out to examine the role of stockbrokers in the internationalization of capital markets in Kenya. The main objective of this study was to examine the role of stockbrokers in the internationalization of capital markets in Kenya. The specific objectives were to: examine the role of stockbrokers in facilitating cross-listing, foreign investment and offshoring in advancing the internationalization of Capital Markets in Kenya and finally establish the factors that affect the role of stock brokers in contributing to the internationalization of capital markets in Kenya.

\section{Literature Review}

Internationalization of Capital Markets: The internationalization of financial markets is one of the focal points in the discussion about recent globalization trends. These discussions suggest that capital can move freely between countries. The internationalization of capital markets in Kenya can therefore be viewed from the perspective of how freely information and securities move, and the vehicles that facilitate the same, i.e. financial brokers (Fernhaber \& Li, 2013). Capital markets internationalisation requires the utilisation of one among the six generic strategies available, such as export orientation, business transfer, global integration, franchising, licensing, foreign subcontracting, and export partnership. Through export orientation, a firm has the ability of entering a foreign market without necessarily outsourcing to other capital markets available. Value creation processes takes place domestically while sales are carried out internationally (Ahmed, 2011). Export orientation is considered the most favourable strategy, especially within fixed costs industry. This strategy is considered as a market seeking strategy, which the Kenyan capital market can take into consideration to enter an international market. The strategies of internationalisation have led to value creation activities, which answer questions such as what to internationalise. In the aspect of internationalisation modes, the varying degrees of risk exposure, commitment, and control, answers questions such as how to carry out the process of internationalisation (Kahiya, 2013).

Foreign operations define the process of global integration. As a result, different strategies and modes of international market entry are regarded as benefits, which make the process of market entry easy. Despite the benefits, there are also some barriers, which make the process of realizing the internationalisation strategies difficult. This includes issues such as trade barriers. Trade barriers include issues such as trade tariffs, quotas, costs of logistics, national regulations, the effects of exchange rates, managerial difficulties, and heterogeneous preferences (Andersson, 2000). In addition to trade barriers, difficulties also arise from transfer barriers such as, the difficulties associated with managerial aspects. These may include governance issues, complexities of coordination, issues of discrimination in the foreign market, and hindrance to the internationalization of value creation. Internationalisation modes can also be considered as aids in the process of achieving an internationalisation strategy. Various internationalisation modes within this context include ownership-based controls, rights, mixed ownership modes, and non-equity modes. According to Sun (2009), there are three main streams of research in internationalization. The first stream is following the eclectic paradigm (Dunning \& McKaig-Berliner, 2002) which highlights the importance of transaction cost and ownership advantage. A Multinational Enterprise is seen as an exploiter or coordinator of resources, a carrier of firm-specific assets, or an "arbitrager" of cheaper inputs (Peng, 2004). It explains why firms decide to start investing abroad, the preconditions or firm specific advantages, where they invest, that is, where the location advantages complement their ownership- specific advantages are available, and why they select Foreign Direct Investment out of many forms of foreign market entry. 
The OLI theory also known as the eclectic paradigm has been developed by John Dunning in a series of publications. The important aspect of OLI theory is that the location and Ownership advantages are necessary, but not sufficient, conditions for Foreign Direct Investment. They should be complemented by internationalization, which helps in taking the advantages of such conditions. Śliwiński (2012) applied the Eclectic Paradigm to the banking sector. He argued that there are locational advantages, which may include follow-the-client, country specific regulations, and entry restrictions. Internationalization advantage can be informational advantages and access to local deposit bases. Another theory similar to eclectic paradigm is the Investment Development Path paradigm (IDP). The dynamic paradigm proposed by Ozawa (1992) based on Japan experiences. Inward and Outward FDI are regarded as development catalysts. Ozawa claims that firms that start losing comparative advantages, because of the growth of wages for instance start to invest abroad. The dynamic paradigm is very similar to IDP model. This model has been used in working out relocation models explaining the behaviour of multinationals.

The second stream follows the tradition of Uppsala process model (Johanson \& Vahlne, 1977) and evolutionary approach. It identifies the different development stage of internationalization, and treats Multinational Enterprises as a learner, knowledge acquirer and market power accumulator. The Nordic or sequential internationalization model (Beck \& Fuchs, 2004) is mainly a descriptive theory. Originally it looked at which firms start to invest abroad and in which forms they enter foreign markets. The third stream comes from international entrepreneurship (Chen \& Yhen, 2011). Firms rely strongly on alternative governance structures to access resources, establish foreign location advantages, and then control over unique resources. This accelerated internationalization approach emphasizes the entrepreneurship of firm founders or managers, and is grounded in the study of entrepreneurship (Wrona \& Gunnesch, 2012).

Role of Stockbrokers in the Internationalization of Capital Markets: Stockbrokers assume the main role of channelling of monies between lenders and borrowers. This form of intermediation facilitates social welfare via the channelling of resources to uses that yield the highest returns for investors. In other words, this process can also be termed as the 'transformation of assets'. Intermediation provides value-addition but there are potential "externalities". One intermediary's actions can have consequences for the entire system (Xue, Zheng \& Lund, 2013). The growth of an economy's output depends on the rise in the level of the proportion of investments arising from the input and outputs of goods and services. Stockbrokers are important to the economy of any country in that they have an important role to play. Stockbrokers issues financial claims to get hold of the funds to the market participants. Further, the funds are invested in form of loans or securities (Beck, \& Fuchs, 2004). Capital market development literature indicates that regional integration is important for stock market development in smaller emerging countries (Wrona \& Gunnesch, 2012). Proponents of financial markets internationalization have argued that regional and global integration can bring greater efficiency, synergies, economies of scale, attract the foreign flow of funds; foster risk sharing and portfolio diversification, and act as an impetus to financial sector reforms (Chen, Hsu \& Caskey, 2013). Off shoring refers to the purchase of financial derivatives or securities away from the local or domestic market. As markets converge in the wake of the internationalization process, there is an increased need to educate, inform, and take appropriate actions on behalf of investors with the desire to invest abroad. As a major financial intermediary, stockbrokers fill in this gap by providing the much needed information, which they disseminate to firms and individuals desiring to invest outside their local country domains. As such, stockbrokers serve the role of advisory services on one hand, while acting as brokering agents by linking the off shore investments with local clientele. Off shoring is the purchase of intermediate services, even though the distinction between final and intermediate services is a difficult one to make in some cases, and may not be very meaningful in the case of certain types of services.

The development of an equity market goes hand in hand with the financial reforms that a country has been undertaking. The reforms ensure improvements in domestic resources mobility through the development of both banking and non-banking components of the financial market. Reforms are also directed towards the improvement of access to global financial markets through the acts of liberalization of the external capital accounts, to allow free capital movement. Reforms are advantageous in that they aid in the reduction of the financial intermediation costs because of enhanced competition within the financial sector. They also did that by doing away with the existing institutional barriers, and ensuring an equal fiscal treatment of the financial instruments. Utilising reforms also ensures the strengthening of the regulatory environment with an aim of 
facilitating a smooth functioning system (Oesterle, Richta \& Fisch, 2013). The government has also ensured advancement in the level of capital development. This is because of the rapid development of the Eurodollar Market available offshore, which contributed to the surge within the economy of the developing country (Kubo, 2006). In cross-listing a firm lists its shares for trading on at least two stock exchanges located in different countries (Rienda, Claver \& Quer, 2013). To accommodate a wide variety of firms, exchanges have designed several listing categories, each with a different set of requirements and, to the extent that investors are knowledgeable about this structure, varying potential benefits. Cross listing is perceived to bring about improved access to more investors, greater liquidity, higher market share and lower cost of capital. However, Hsu, Chen \& Cheng (2013) argues that it has not been established empirically what the real effects of crossborder listing on a firm's financial performance.

Constructs and variables: Regardless of the form or nature of investing, the use of brokerage firms is imperative in completing the investing process. The entire concept of the movement of securities by various stakeholders (foreigners and locals) into various markets (local and off shoring) completes the internationalization spectre within capital markets. The postulated relationship between stockbroker role in various areas and internationalization of capital markets is illustrated in Figure 1 below.

Figure 1: Conceptualization of the role of Brokers in Internationalization of Capital Markets

Independent Variables

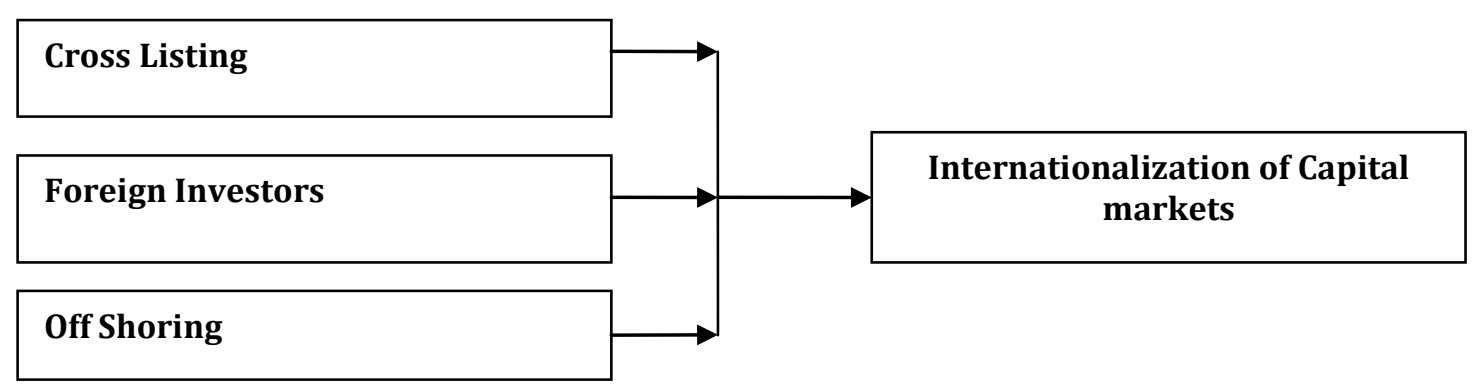

In order to measure the variables it is necessary to assign them operational measure. The components of the dependent and independent variables operate differently depending on the variable. In the independent variable, cross listing is measured by the role played by the brokers in the process of internationalization. The brokers play a key role in research that provides information to the firms cross listing. As a major financial intermediary, brokers fill in this gap by providing the much-needed information, which they disseminate to firms and individuals desiring to invest outside their local country domains. As such, stock brokers serve the role of advisory services on one hand, while acting as broking agents by linking the off shore investments with local clientele as well as linking local investments to foreign investors. The dependent variables are measured by the number of stocks listed in NSE and other securities exchanges for the component of cross listing; the number of foreign investors in the local market- NSE for the component of foreign investors; and the number of local investors participating in off shore investments for the component of off shore. The indicators of variables in this study are presented in table 1 below.

\section{Methodology}

This study adopted a descriptive survey. The choice of this .design was based on the fact that in the study, the focus was on the state of affairs already existing in the area of interest. The study entailed carrying out a survey of stock brokers focussing on the issues of interest to the study (Chen, Hsu \& Caskey, 2013). The target population of this study was all the 19 stockbrokerage firms licensed to operate at the Nairobi Securities Exchange (NSE) that represented the study unit of analysis. The study adopted a census survey technique with emphasis on representatives of the departments in the stockbrokerage firms that dealt with customers and business development which led to the internationalization processes. The departments of interest were research departments, dealing department and customer service. For purposes of this study, stratified, purposive sampling was employed in selecting the target respondents. Target respondents comprised of the 
heads of these departments across the firms, translating to 57 targeted respondents in total as shown in table 2 below.

Table 1: Operationalization of Variables

\begin{tabular}{lll}
\hline Variables & Components & Specific task indicator \\
\hline Independent variables & Cross-listing & - Provision of information \\
Role of stock brokers & & - Transaction processing \\
& Foreign investors & - Sourcing \\
& Off-shoring & - Provision of Information \\
& & - Facilitating the Transaction \\
& & - Provision of Information \\
$\begin{array}{l}\text { Internationalization of Capital Market } \\
\text { Indent Variable }\end{array}$ & - Facilitating the Transaction \\
& - Number of stocks listed in NSE and \\
& & other securities exchanges \\
& & Number of foreign investors in the local \\
& & market- NSE \\
& & Number of local investors participating \\
\end{tabular}

Table 2: Distribution of Respondents

\begin{tabular}{lcccc}
\hline Department & $\begin{array}{l}\text { Number of brokerage } \\
\text { firms }\end{array}$ & $\begin{array}{l}\text { No. of respondent } \\
\text { each department }\end{array}$ & $\begin{array}{c}\text { from } \\
\text { Total } \\
\text { across firms }\end{array}$ \\
\hline Research & 19 & 1 & 19 \\
Dealing & 19 & 1 & 19 \\
Customer service & 19 & 1 & 19 \\
Total & $\mathbf{5 7}$ & & $\mathbf{5 7}$ \\
\hline
\end{tabular}

Ketchen \& Hult (2006) defines data collection as a means by which information is obtained from the selected subjects of an investigation. Data collection is one of the most important aspects of any type of research. The results of a study are pre-determined by accurate data collection, inaccuracy of which leads to invalid results (Groves \& Valsamakis, 1998). This survey relied on both quantitative and qualitative data collection. These methods were in line with the operationalization of the study variables (Figure 1). Primary data was collected by use of a semi-structured questionnaire. According to Yin (2009), questionnaires are the most effective and reliable and also inexpensive compared to other data collection methods. The questionnaire had both open and closed ended questions. Pilot test was carried out towards ensuring reliability and validity. According to Cooper \& Schilder, (2003) 1\% of the sample is sufficient for purposes of a pilot test. The most common internal consistency measure known as Cronbach's alpha $(\alpha)$ was used. The recommended value of 0.7 was used as a cut-off of reliabilities. Reliability is the consistency of a set of measurement items while validity indicates that the instrument is testing what it should (Cronbach, 1951).

Data was analyzed using both descriptive and inferential statistics. Descriptive statistical tools aided in describing the data and determining the respondents' degree of agreement with the various statements under each factor. Multiple regression analysis was also employed to establish the influence of the role of stock brokers on internalization of capital markets in Kenya. Data analysis was done with the help of software programme SPSS. The regression equation used was expressed in the following equation:

$Y=a+\beta_{1} X_{1}+\beta_{2} X_{2}+\beta_{3} X_{3}+\varepsilon$, Where,

$\mathbf{Y}=$ Internationalization of capital market,

$\mathbf{a}=$ Constant

B1- $\boldsymbol{\beta 3}=$ Coefficients of Regression

$\mathbf{X}_{\mathbf{1}}=$ Off Shoring

$\mathbf{X}_{2}=$ Foreign Investors

$\mathbf{X}_{3}=$ Cross Listing

$\boldsymbol{\varepsilon}=$ Error Term

$B_{1} \ldots B_{3}=$ regression coefficient of four variables. 


\section{Results and Discussion}

Out of the targeted 57 respondents, a response rate of $82.5 \%$ was achieved and this is considered satisfactory to make conclusion for the study. Borsboom (2005) argues that a response rate of $50 \%$ is adequate, while a response rate greater than $70 \%$ is very good. Therefore based on this assertion; the response rate in this case of $83 \%$ is very good.

Reliability Analysis Results: The analysis involved questionnaires from seven respondents and the Alpha coefficients were all greater than 0.7 indicating an acceptable reliability of the instruments. Cooper \& Schindler (2003) indicates that a coefficient of 0.7 is an acceptable reliability coefficient. Table 3 shows this result (the Cronbach's alpha).

Table 3: Reliability analysis results - Cronbach Alpha coefficients

\begin{tabular}{lll}
\hline Variable & Cronbach's Alpha & No of Items \\
\hline $\begin{array}{l}\text { Stock brokers role in the internationalization of capital } \\
\text { markets }\end{array}$ & .7069 & 7 \\
\hline
\end{tabular}

\section{Descriptive analysis results}

Role of stock brokers in cross listing in the Internationalization of Capital Markets: One of the objectives of this study was to examine the contribution of stock broker role in cross-listing to internationalization of capital markets. Respondents were asked to indicate their level of agreement with various statements appropriate to the role of stock brokers in cross listing in the Internationalization of Capital Markets. From the study findings, majority (81) agreed that stock brokers list ordinary shares of a firm on a different exchange other than its home stock exchange. Also, $62 \%$ agreed that to accommodate a wide variety of firms, exchanges have designed several different listing categories, each with a different set of requirements and, to the extent that investors are knowledgeable about this structure, varying potential benefits. Table 4 below shows this finding.

Table 4: Role of stock brokers in cross listing

Statements Mean

Std dev

1. Transaction processing (Financial brokers list ordinary shares of a firm on a different exchange other than its home stock exchange)

$4.8 \quad 0.32$

2. Provision of information (facilitation of access to information on listing categories, listing requirements, knowledgeable about structure, varying potential benefits).

This finding is based on responses on a likert type scale of between 1 and 5, where 1 and 5 represents to a very small and very large extent respectively

Stock brokers' role in off shoring: The study also sought to establish whether the stock brokers' role in offshoring contributes to capital market internationalization. $100 \%$ of the target the respondents indicated that stock brokers provides the much-needed information, which they disseminate to firms and individuals desiring to invest outside their local country domains. Eighty one percent (81\%) agreed that stock brokers purchase financial derivatives or securities away from the local or domestic market. This finding is shown through table 5 below. 
Table 5: Financial brokers' role in off shoring

\begin{tabular}{l} 
Statements \\
$\begin{array}{l}\text { 1.Sourcing (Financial brokers purchase of financial derivatives or securities } \\
\text { away from the local or domestic market) }\end{array}$ \\
$\begin{array}{l}\text { 2. Provision of information (Financial brokers provide the much-needed } \\
\text { information, which they disseminate to firms and individuals desiring to invest } \\
\text { outside their local country domains) }\end{array}$ \\
$\begin{array}{l}\text { 3. Facilitating the transaction (purchase of certain types of intermediate } \\
\text { services) }\end{array}$ \\
\hline
\end{tabular}

This finding is based on responses on a likert type scale of between 1 and 5, where 1 and 5 represents to a very small and very large extent respectively

Role of stock brokers in foreign investor in the Internationalization of Capital Markets: Stock brokers play a role in fostering foreign investment. Hence, this study sought to establish the role of stock brokers as an instrument in the foreign investor in the internationalization of Capital Markets. Findings indicate that stock brokers assume the main role of channelling of monies between lenders and borrowers. In this sense, this form of intermediation facilitates social welfare via the channelling of resources to uses that yield the highest returns for investors. Further, respondents were asked to indicate the extent the stock brokers play their role as foreign investors in the internationalization of capital markets. Findings indicate that majority $(63 \%)$ indicated that foreign investors played a role in the internationalization of capital markets in Kenya to a great extent, $23 \%$ indicated that foreign investors played a role in the internationalization of capital markets in Kenya to a moderate extent, while 14\% indicated that foreign investors played a role in the internationalization of capital markets in Kenya to a very great extent.

Table 6: Role of stock brokers in foreign investor support

$\begin{array}{lcc}\text { Statement } & \text { Mean Std Dev }\end{array}$

i. Identification and sourcing investment opportunities (Stockbrokers introduce foreign investors to the local market hence playing a significant role in the internationalization of capital market in Kenya)

$4.6 \quad 0.26$

ii. Provision of information (Stockbrokers provide the necessary information required by foreign investors regarding the requirements for their participation in the local market as well as information regarding the stocks and other instruments trading in the NSE)

$4.8 \quad 0.32$

iii. Facilitate transaction (Stockbrokers facilitate the transactions between the foreign investors and the local markets and ensure that the securities are securely in the foreigners' name)

$4.6 \quad 0.24$

This finding is based on responses on a likert type scale of between 1 and 5, where 1 and 5 represents to a very small and very large extent respectively

The study sought to establish the respondents' level of agreement with various statements with regard to foreign investor as a role played by stockbrokers in the Internationalization of capital markets. Respondents strongly agreed that stockbrokers provide the necessary information required by foreign investors regarding the requirements for their participation in the local market as well as information regarding the stocks and other instruments trading in the NSE as shown by a mean of 4.8. The respondents also agreed that stockbrokers introduce foreign investors to the local market hence playing a significant role in the internationalization of capital market in Kenya and also facilitate the transactions between the foreign investors and the local markets and ensure that the securities are securely in the foreigners' name as shown 
by a mean of 4.6. This finding is shown in table 6 above. Study findings reveal that stock brokers role in the three areas (cross-listing, off-shoring and foreign investment) indeed do contribute to capital market internationalization, with means across the various specific roles (opportunity sourcing, information provision and transaction facilitation) scored over 4.0.

Factors affecting stock broker's Role in the Internationalization of Capital Markets: The internationalization of capital markets in Kenya has been at a noticeable low pace and stock brokers' role is perceived as limited. Respondents were asked to rank factors affecting stock brokers' role in the internationalization of capital markets. According to the findings as shown in Table 7, the government affected stock brokers' role in the Internationalization of capital markets to a great extent as shown by a mean 4.8, Lack of awareness and knowledge on innovative strategies affected stock brokers' role in the internationalization of capital markets to a great extent as shown by a mean 4.7, adequate financial resources and support affected stock brokers' role as a broker and in the internationalization of capital markets to a great extent as shown by a mean 4.1, further, availability of adequate infrastructure affected stock brokers' role in the internationalization of capital markets to a great extent as shown by a mean 3.9, lastly, dealing/trading costs affected stock brokers' role in the internationalization of capital markets to a great extent as shown by a mean 3.6.

\begin{tabular}{lcc} 
Table 7: Ranking of factors affecting stock broker's role in capita market & internationalizatio \\
\hline Factor & & Mean \\
& & Std dev \\
\hline Availability of adequate infrastructure & 3.9 & 0.18 \\
Adequate financial resources and support & 4.1 & 0.22 \\
Lack of awareness and knowledge on innovative strategies & 4.7 & 0.05 \\
& 3.6 & 0.16 \\
Dealing/Trading Costs & 4.8 & 0.32 \\
\hline
\end{tabular}

This finding is based on responses on a likert-type scale of between 1 and 5, where 1 and 5 represents to a very small and very large extent respectively.

Areas of government issues and regulations and, awareness and knowledge on innovative strategies on the part of stock brokers tops as the most critical factors that affect stock brokers role in capital market internationalization ( with means of 4.8 and 4.7 respectively). Although the other factors (infrastructure, financial resources, dealing cost) also influence the stockbroker contribution in the internationalization of capital markets, the two factors require close attention.

\section{Inferential statistics}

Regression analysis results: The $\mathrm{R}^{2}$ is called the coefficient of determination and shows variability in dependent variable explained by the variability in independent variable. This value tells us how internationalization of capital market varied with off shoring, foreign investors and cross listing. The $\mathrm{R}^{2}$ value of 0.7812 implies that $78.1 \%$ of the variations in the dependent variable (internationalization of capital market) are explained by the variations in independent variables (Off shoring, foreign investors and cross listing). Further, the Durbin Watson value is greater than 2 implying there is no autocorrelation. The value of $d$ always lies between 0 and 4 . If the Durbin-Watson statistic is substantially less than 2 , there is evidence of positive serial correlation. The study therefore identifies off shoring, foreign investors and cross listing as critical roles played by stock brokers for internationalization of capital market. It further establishes that the relations between the three roles drive internationalization of capital market, consequently a need to implement a strategy to enhance the three areas. 
Table 8: Regression Model Summary of the effect of Independent variable

\begin{tabular}{|c|c|c|c|c|c|c|}
\hline \multicolumn{7}{|c|}{ Model summary } \\
\hline Model & $\mathbf{R}$ & R Square & $\begin{array}{l}\text { Adjusted } \\
\text { Square }\end{array}$ & $\mathbf{R}$ & $\begin{array}{l}\text { Std. Error of the } \\
\text { Estimate }\end{array}$ & Durbin Watson \\
\hline 1 & .8839 & .7812 & .7685 & & .1458 & 2.220 \\
\hline
\end{tabular}

Table 9: ANOVA results

\begin{tabular}{|c|c|c|c|c|c|c|}
\hline Model & & $\begin{array}{l}\text { Sum } \\
\text { Squares }\end{array}$ & df & Mean Square & $\mathbf{F}$ & Sig. \\
\hline \multirow[t]{3}{*}{1} & Regression & 6.227 & 4 & 1.557 & 4.398 & $.034(\mathrm{a})$ \\
\hline & Residual & 18.831 & 42 & .649 & & \\
\hline & Total & 25.059 & 46 & & & \\
\hline
\end{tabular}

a Predictors: (Constant), Off Shoring, Foreign Investors and Cross Listing

$b$ Dependent Variable: Capital Market Internationalization

The significance value is .034 which is less that 0.05 thus the model is statistically significant in predicting Off Shoring, Foreign Investors and Cross Listing).

Multiple regression analysis: A multiple regression analysis was conducted. From the regression model, holding off shoring, foreign investors and cross listing constant, Internationalization of Capital Market would be 1.147. It's established that a unit increase in stock brokers' role as foreign investors would cause an increase in internationalization of Capital Market by a factor of 0.488 , a unit increase in off shoring would cause an increase in internationalization of Capital Market by a factor of 0.434 . Also a unit increase in cross listing would cause an increase in internationalization of Capital Market by a factor of 0.269 . This shows that there is a positive relationship between internationalization of Capital Market and, Off Shoring, stock brokers' role as foreign investors and Cross Listing. The Unstandardized beta coefficients column in Table 10 below were used to obtain the overall equation as suggested in the conceptual framework. The regression equation was $\left(Y=\beta 0+\beta_{1} X_{1}+\beta_{2} X_{2}+\beta_{3} X_{3}+\varepsilon\right)$ : When these beta coefficients are substituted in the equation, the model becomes:

$\mathrm{Y}=1.147+0.488 \mathrm{X}_{1}+0.434 \mathrm{X}_{3}+0.269 \mathrm{X}_{4}+0.00$

Where:

$\mathrm{Y}=$ Internationalization of Capital Market, $\mathrm{X} 1$ = Off Shoring, $\mathrm{X} 2$ = stock brokers' role as foreign investors, $\mathrm{X} 3=$ Cross Listing

Further, the regression analysis results show that the relationship between the factors (Off shoring, cross listing and foreign investor) and capital market internationalization at $95 \%$ confidence level is statistically significant with $\mathrm{p}$ values $<0.05$. The most significant role is in as foreign investors with $\mathrm{p}$ value of 0.01 . This implies that stock brokers role as foreign investors contribute more to the internationalization of capital market in Kenya while stock brokers role in cross listing contribute the least.

Table 10: Coefficient of Determination

\begin{tabular}{llllll}
\hline & \multicolumn{2}{l}{$\begin{array}{l}\text { Unstandardized } \\
\text { Coefficients }\end{array}$} & $\begin{array}{l}\text { Standardized } \\
\text { Coefficients }\end{array}$ & t & Sig. \\
& B & Std. Error & Beta & & \\
\hline (Constant) & 1.147 & 0.393 & & 2.915 & .000 \\
Foreign Investors & .488 & .256 & .186 & 1.908 & .001 \\
Off Shoring & .434 & .195 & .609 & 2.221 & .031 \\
Cross Listing & .269 & .135 & .387 & 1.991 & .003 \\
\hline
\end{tabular}


The study findings that stock brokers contributes positively to capital markets internationalization conforms to study finding by Äijö (2001) who observed that stock brokers plays a big role in capital market internationalization. The finding that capital can move freely between countries and viewed the internationalization of capital markets is enhanced from the perspective of how freely information and securities move, and the vehicles that facilitate the same, through the stock brokerage platforms. According to Johanson \& Valhne (1977) when a firm gathers knowledge, experiences and networks by exporting, it is in a little while able to take the next step and expand its speed of internationalizing.

In regard to the respondents ranking of factors affecting stock broker's role in the internationalization of capital markets, the government, lack of awareness and knowledge on innovative strategies, adequate financial resources and support are ranked as factors that affect to a very great extent stock brokers role in the internationalization of capital markets. Further, the study findings revealed that availability of adequate infrastructure and trading costs affected to a great extent stock brokers role in the internationalization of capital markets. The findings confirms Johanson \& Vahlne (2012) observations that lack of awareness and knowledge on innovative strategies, adequate financial resources and support are some of the factors that affect stock brokers role in the internationalization of capital markets. The study revealed that information availability determined to a very great extent, investment in other countries capital market. According to Sun (2009) the ability of firms to make use of available information and know how sets firms apart from the domestic enterprise because information is itself a key asset or resource that a firm leverages as it operates within the context of unfamiliar host countries. According to the findings, foreign investors play a role in the internationalization of capital markets in Kenya to a great extent. This was confirmed by the regression analysis results that indicated that the relationship between foreign investors role and the capital market internationalization is statistically significant at $95 \%$ confidence level ( $p$-value $0.001<0.05$ ). Further, the regression analysis results indicated that the relationship between off shoring role and capital market internationalization was statistically significant at $95 \%$ confidence level ( $p$-value $0.003<0.05$ ). The regression analysis results indicated that the relationship between cross listing role and the capital market internationalization was statistically significant at $95 \%$ confidence level ( $p$-value $0.03<0.05$ ).

\section{Conclusion and Recommendations}

The study concludes that indeed stock brokers contribute to capital market internationalization. The stock brokers' role in the three areas (cross-listing, off-shoring, and foreign investor) influences the level of internationalization of capital markets in Kenya. The stock brokerage platform facilitates capital to move freely between countries and this is enhanced from the perspective of sourcing of opportunities, searching and making relevant information available to firms and facilitating transactions. The study further concludes that the government, lack of awareness and knowledge on innovative strategies, adequate financial resources, availability of adequate infrastructure and trading costs affects to a great extent stock brokers role in the internationalization of capital markets. The study recommends that stock brokers should invest in information search, embrace technology and innovative strategies for enhanced efficiency and effectiveness in contributing to taking capital market internationalization to a higher level. Further stock brokers should strengthen their institutional capacities in terms of resources, infrastructures, processes and systems. The government and policy makers should direct efforts towards addressing the various bottlenecks that hinder the effectiveness of the stock brokers in the internationalization of capital markets in Kenya. The government and other players in the capital markets sector should strive towards making the environment conducive for

doing business locally and across capital market borders as this would positively contribute to capital market internationalization and development.

\section{References}

Ahmed, A. (2011). International Financial Integration, Investment, and Economic Performance in SubSaharan African Countries. Global Economy Journal, 11(4), 1-26.

Äijö, M. (2001). Stock brokers role in capital market internationalization. Internalization Theory and Practice, 23(3), 11-27.

Beck, T. \& Fuchs, M. (2004). Structural Issues in the Kenyan Financial System: Improving Competition and 
Access. California, USA: World Bank, Development Research Group, Finance Team.

Benito, G., Petersen, B. \&Welch, L. (2009). Towards more realistic conceptualisations of foreign operation modes. Journal of International Business Studies, 40(9), 1455-1470.

Bluhm, D. J., Harman, W., Lee, W. \& Mitchell, T. (2011). Qualitative Research in Management: A Decade of Progress. Journal of Management Studies, 48, 1866-1891.

Borsboom, D. (2005). Measuring the mind. Conceptual issues in contemporary psychometrics. Cambridge: Cambridge University Press.

Chen, H., Hsu, C. \& Caskey, D. (2013). Internationalization of Taiwanese manufacturing firms: The evolution of subsidiary mandates and capabilities. Asian Business \& Management, 12(1), 37-60.

Chen, P. \& Wu, S. (2013). On international stock market co-movements and macroeconomic risks. Applied Economics Letters, 20(10), 978-982.

Chen, T. \& Yhen, P. (2011). Taiwanese Foreign Direct Investment: The Risks of De-Industrialization. Journal of Industry Studies, 2(1), 57-68.

Cooper, D. \& Schindler, P. (2003). Business Research Methods ( $8^{\text {th }}$ edition). USA:McGraw-Hill.

Cronbach, L. (1951). Coefficient alpha and the internal structure of tests. Psychometrika, 16, 297-334.

Dunning, J. \& McKaig-Berliner, A. (2002). The geographical sources of competitiveness: the professional business service industry. Transnational Corporations, 11(3), 1-38.

Fernhaber, S. \& Li, D. (2013). International exposure through network relationships: Implications for new venture internationalization. Journal of Business Venturing, 28(2), 316-334.

Fonfara, K. (2011). A typology of company behaviour in the internationalisation process (a network approach). Poznan University of Economics Review, 11(2), 5-25.

Groves, G. \& Valsamakis, V. (1998). Supplier-customer relationships and company performance. The International Journal of Logistics Management, 9 (2), 51-63.

Hsu, W., Chen, H. \& Cheng, C. (2013). Internationalization and firm performance of SMEs: The moderating effect of CEO attributes. Journal of World Business, 48(1), 1-12.

Johanson, G. \& Vahlne, M. (2012). Foreign Direct Investment: The Risks of De-Industrialization, in Journal of Industry Studies, 2(1), 57-68.

Johanson, J. \& Vahlne, J. (1977). The Internationalization Process of the Firm A Model of Knowledge Development and Increasing Foreign Market Commitments. Journal of International Business Studies, 8(1), 23-32.

Kahiya, E. (2013). Export barriers and path to internationalization: A comparison of conventional enterprises and international new ventures. Journal of International Entrepreneurship, 11(1), 3-29.

Ketchen, G. \& Hult, T. (2006). Bridging organization theory and supply chain management: The case of best value supply chains. Journal of Operations Management, 25(2), 573-580.

Kubo, K. (2006). The Degree of Competition in the Thai Banking Industry before and after the East Asian Crisis, Institute of Developing Economies, Discussion Paper No. 56.

Mugwe, D. (2012). NSE Investors Gain Sh290bn as Foreigners Lift Share Prices. Business Daily. Issue No. 1428.

Oesterle, M., Richta, H. \& Fisch, J. (2013). The influence of ownership structure on internationalization. International Business Review, 22(1), 187-201.

Ozawa, T. (1992). Foreign Direct Investment and Economic Development. Transnational Corporations, 1(1) 27-54

Peng, M. (2004). Identifying the big question in international business research. Journal of International Business Studies, 35(2), 99-108.

Rienda, L., Claver, E. \& Quer, D. (2013). The internationalisation of Indian multinationals: determinants of expansion through acquisitions. Journal of the Asia Pacific Economy, 18(1), 115-132.

Śliwiński, R. (2012). Internationalization strategies of Polish fast growing enterprises. Poznan University of Economics Review, 12(1), 17-39.

Sparrow, P., Farndale, E. \& Scullion, H. (2013). An empirical study of the role of the corporate HR function in global talent management in professional and financial service firms in the global financial crisis. International Journal of Human Resource Management, 24(9), 1777-1798.

Sun, N. (2009). International Investment and International Trade in the Product Cycle. Quarterly Journal of Economics, 80, 190-207.

Trąpczyński, P. \& Wrona, T. (2013). From going international to being international - strategies for international competitiveness. Poznan University of Economics Review, 13(1), 89-114. 
Wrona, T. \& Gunnesch, M. (2012). On the role of theory in qualitative research, TUHH-Working Paper, Hamburg.

Xue, Q., Zheng, Q. \& Lund, D. (2013). The Internationalization of Service Firms in China: A Comparative Analysis with Manufacturing Firms. Thunderbird International Business Review, 55(2), 137-151.

Yin, R. (2009). Case study research: design and methods, Sage Publications, Thousand Oaks, CA. 